\title{
New Combinations in Gnaphalium (Asteraceae: Inuleae)
}

\author{
G. Ledyard Stebbins \\ Department of Genetics, University of California, Davis, California 95616, U.S.A.
}

\begin{abstract}
David J. Keil
Biological Sciences Department, California Polytechnic State University, San Luis Obispo, California 93407, U.S.A.
\end{abstract}

ABSTRaCt. Because of extensive morphological intermediacy, plants formerly distinguished at the species level as Gnaphalium beneolens, G. microcephalum, G. thermale, and G. wrightii are treated as intergrading races of the widespread $G$. canescens. The new combinations, G. canescens subsp. beneolens, G. canescens subsp. microcephalum, and G. canescens subsp. thermale are made.

In preparing the treatment of Gnaphalium L. for the forthcoming flora of California, The Jepson Man$u a l$, we have found that the species currently recognized as G. beneolens A. Davidson, G. thermale E. Nelson, G. microcephalum Nutt., and G. wrightii A. Gray intergrade to such a degree with respect to the characters used in current keys (Ferris, 1960; Munz, 1959, 1968, 1974) to differentiate themdecurrent versus nondecurrent leaf bases, nature of tomentum, character of capitulescence, size and shape of heads, and acute versus obtuse phyllary tips-that they cannot consistently be separated from each other. In addition, G. wrightii of easternmost California, Arizona, New Mexico, and northern Mexico is indistinguishable from $G$. $c a$ nescens DC. of central Mexico. These entities are therefore all merged into a single polymorphic species, G. canescens. Recognizable geographic tendencies in variation are maintained as subspecies. The following new combinations are therefore proposed:

Gnaphalium canescens DC. subsp. beneolens (A. Davidson) Stebbins \& Keil, comb. nov. Gnaphalium beneolens A. Davidson, Bull. So. Calif. Acad. Sci. 17: 17. 1918.
Gnaphalium canescens DC. subsp. microcephalum (Nutt.) Stebbins \& Keil, comb. nov. Gnaphalium microcephalum Nutt., Trans. Amer. Phil. Soc. n.s., 7: 404. 1841.

Gnaphalium canescens DC. subsp. thermale (E. Nelson) Stebbins \& Keil, comb. nov. Gnaphalium thermale E. Nelson, Bot. Gaz. (Crawfordsville) 30: 121. 1900.

Gnaphalium canescens subsp. canescens (including G. wrightii) occurs from the southwestern United States to central Mexico. In the desert mountains of eastern California it grades into subspecies microcephalum, a race chiefly of southern California. This in turn grades into subspecies beneolens in the South Coast Ranges of California. Plants of the Sierra Nevada foothills are mostly assignable to subspecies beneolens, but above 1,000 m, plants agree more with subspecies thermale. The latter ranges eastward to the Rocky Mountains and northward to British Columbia. Descriptions of these taxa and their ranges are included in our treatment of Gnaphalium in The Jepson Manual.

\section{Literature Cited}

Ferris, R. S. 1960. Compositae. Pp. 98-613 in L. Abrams \& R. S. Ferris, Illustrated Flora of the Pacific States, vol 4. Stanford Univ. Press, Stanford.

Munz, P. A. 1959. A California Flora. Univ. California Press, Berkeley.

- 1968. Supplement to A California Flora. Univ. California Press, Berkeley.

. 1974. A Flora of Southern California. Univ California Press, Berkeley. 